\title{
PEMANFAATAN TEPUNG BONGGOL PISANG KEPOK (MUSA ACUMINATA BALBISIANA) MENJADI CHOCO COOKIES
}

\author{
Made Wira Lega Saputra, Risa Panti Ariani, Damiati. \\ Jurusan Teknologi Industri \\ Universitas Pendidikan Ganesha \\ Singaraja, Indonesia \\ e-mail : wira.lega.saputra@undiksha.ac.id, risa.panti@undiksha.ac.id, \\ damiati@undiksha.ac.id
}

\begin{abstract}
Abstrak
Penelitian eksperimen ini bertujuan untuk mengetahui (1) formula choco cookies tepung bonggol pisang kepok (2) kualitas choco cookies tepung bonggol pisang kepok dari rasa, aroma dan tekstur. Objek penelitian ini adalah proses pembuatan dan kualitas choco cookies tepung bonggol pisang kepok dari aspek rasa, aroma, dan tekstur. Panelis yang dipilih adalah panelis terlatih terdiri dari guru dan dosen tata boga berjumlah 19 orang. Metode yang digunakan adalah metode eksperimen dan metode observasi. Data kualitas choco cookies tepung bonggol pisang kepok dikumpulkan melalui uji organoleptik mutu hedonik dengan skala 3 tingkatan. Analisis data menggunakan analisis deskriptif kualitatif dan kuantitatif. Hasil penelitian, ditemukan bahwa (1) formula choco cookies tepung bonggol pisang kepok sebagai berikut tepung bonggol pisang kepok $150 \mathrm{~g}$, margarin $180 \mathrm{~g}$, choco chip $150 \mathrm{~g}$, gula halus $150 \mathrm{~g}$, cokelat bubuk $25 \mathrm{~g}$, kuning telur $20 \mathrm{~g}$ dan vanilli $4 \mathrm{~g}(2)$ kualitas choco cookies tepung bonggol pisang kepok dilihat dari aspek rasa berada pada kategori baik dengan skor rata-rata 2,94 artinya memiliki rasa manis dan gurih. Aspek aroma berada pada kategori baik dengan skor rata-rata 2,89 artinya memiliki aroma khas bonggol pisang kepok. Aspek tekstur berada pada kategori baik dengan skor rata-rata 2,78 artinya memiliki tekstur yaitu rapuh.
\end{abstract}

Kata Kunci : choco cookies, kualitas, tepung bonggol pisang kepok, formula.

\begin{abstract}
This experimental research is aimed to know (1) the formula of kepok banana hump flour choco cookies (2) the quality of kepok banana hump flour seen from flavor, aroma and texture. The object of this study is process and quality of kepok banana hump flour choco cookies from the aspect of flavor, aroma and texture. The selected panelists were 19 trained panelists. The method used in this is the method of laboratory and method of observation. The data kepok banana hump flour was collected through organoleptic test of hedonic quality with scale 3 levels and then the data of this study was found some result will be analyzed by using qualitative and quantitative descriptive analysis method. Based on the results of data analysis, it was found (1) the formula of kepok banana hump flour choco cookies is a kepok banana hump flour 150g, margarine $180 \mathrm{~g}$, choco chip $150 \mathrm{~g}$, refined sugar $150 \mathrm{~g}$, cocoa powder $25 \mathrm{~g}$, egg yolk $20 \mathrm{~g}$, and vanillie $4 \mathrm{~g}$ (2) the quality of kepok banana hump flour choco cookies seen from flavor aspect is good category with the average 2,94 has a desired flavor there are sweat and savory, from the aspect aroma is in the good category with the average 2,89 has a distinctive aroma of kepok banana hump flour, from the aspect of the texture is good category with the average 2,78 has a distinctive texture is fragile.
\end{abstract}

Keywords: choco cookies, quality, kepok banana hump flour, formula 


\section{PENDAHULUAN}

Kabupaten buleleng memiliki berbagai macam potensi diantaranya berupa hasil pertanian yang beraneka ragam seperti buah-buahan, salah satu buah yang dihasilkan yaitu buah pisang. Jumlah pohon pisang pada tahun 2017 mencapai 1.513.585 pohon dan jumlah produksi mencapai 28.468 ton dengan kecamatan yang paling banyak memproduksi yaitu kecamatan Gerokgak sebanyak 14.411 ton, pada posisi kedua kecamatan Busungbiu sebanyak 4.072 ton (Dinas Statistik Kabupaten Buleleng, 2018). Pisang yang banyak ditaman di kecamatan Gerokgak dan kecamatan Busungbiu adalah jenis pisang kepok, pisang batu dan pisang mas. Pisang kepok (musa acuminata balbisiana) adalah tanaman buah yang berasal dari kawasan Asia Tenggara (termasuk Indonesia). Bagian tanaman pisang seperti buah, bonggol, daun, batang dan jantung pisang dapat dimanfaatkan. Dari seluruh bagian tanaman pisang buah, daun, batang, dan jantung yang banyak dimanfaatkan menjadi hidangan. Buah pisang diolah menjadi pisang goreng, sale pisang dan lain-lain. Daun pisang dimanfaatkan untuk dekorasi hidangan. Batang pisang terutama yang masih muda diolah menjadi hidangan khas bali yaitu jukut ares (sup batang pisang) dan jantung pisang diolah menjadi hidangan tumis jantung pisang. Berbeda dengan bonggol pisang yang belum dimanfaatkan secara optimal oleh masyarakat.

Bonggol pisang merupakan bagian bawah batang pisang yang menggembul berbentuk umbi, memiliki kulit luar berwarna coklat dan daging bonggol berwarna putih. Bedasarkan observasi awal yang telah dilakukan di desa Patas Kecamatan Gerokgak Kabupaten Buleleng dan desa Tista Kecamatan Busungbiu Kabupaten Buleleng diketahui bahwa bonggol pisang yang sudah selesai dipanen akan dibiarkan mati dan kadang digunakan sebagai pakan ternak, berbeda dengan desa Tista Kecamatan Busungbiu Kabupaten Buleleng memanfaatkan bonggol pisang menjadi tum bungkil atau pepes bonggol pisang (Meliawati, dkk,
2016). Akan tetapi daya simpan dari tum bungkil tersebut tidak tahan lama. Salah satu solusi yang dapat dilakukan agar bertahan lama adalah dengan memanfaatkan limbah bonggol pisang menjadi tepung.

Bedasarkan hasil uji eksperimen menyatakan kandungan gizi tepung bonggol pisang menghasilkan kualitas terbaik dibandingkan pisang raja, pisang mahuli, pisang susu dan pisang ambon.

Tabel 1.

Perbandingan kandungan gizi tepung bonggol pisang kepok dan tepung terigu protein rendah per 100 gram

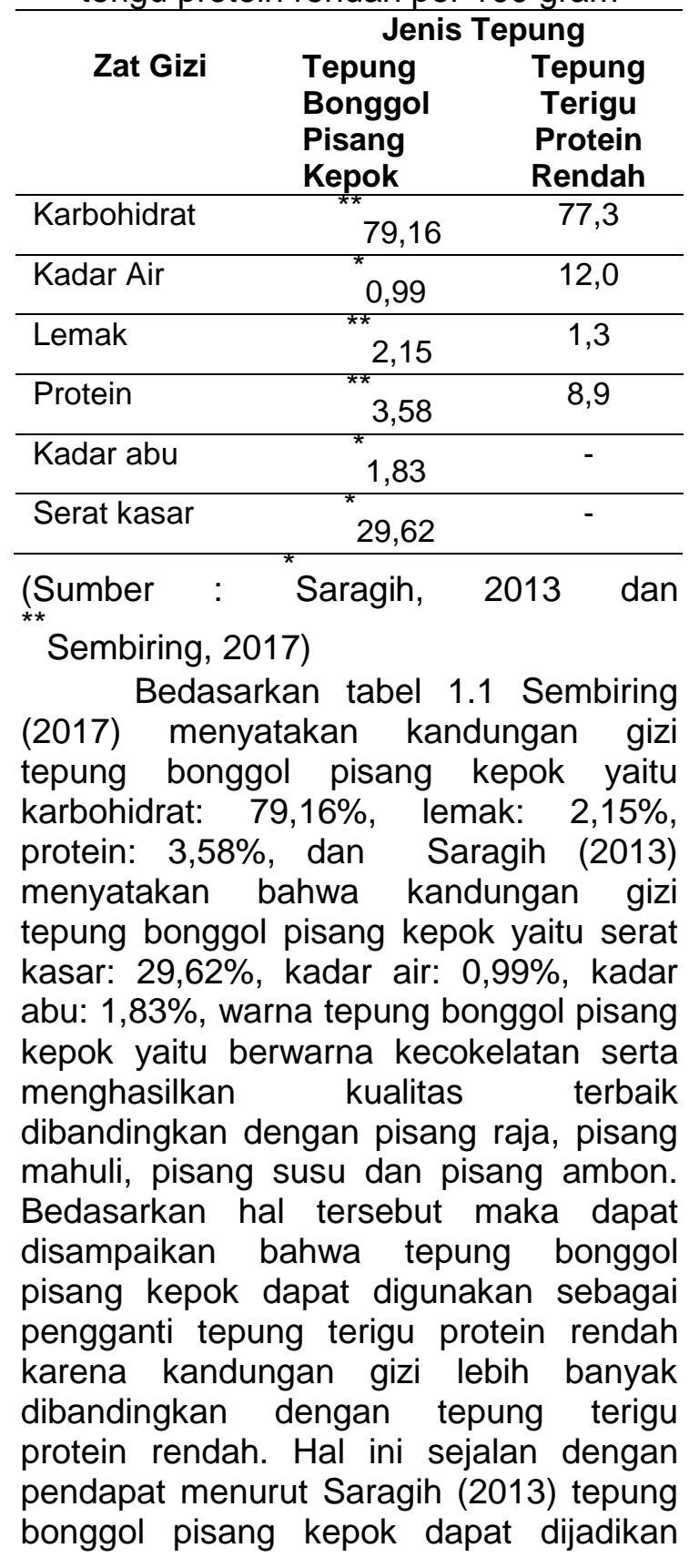


sebagai bahan pengganti tepung terigu protein rendah dalam pengolahan beberapa jenis panganan seperti dalam pembuatan kue kering. Berdasarkan pemikiran ini peneliti membuat tepung dari limbah bonggol pisang kepok sebagai pengganti tepung terigu pada pembuatan choco cookies. Penelitian ini bertujuan untuk mengetahui formula choco cookies tepung bonggol pisang kepok dan untuk mengetahui kualitas choco cookies tepung bonggol pisang kepok dilihat dari aspek rasa, aroma dan tekstur.

Choco cookies merupakan produk cookies, cookies sebagai produk patiseri yang terbuat dari bahan tepung terigu, gula pasir, lemak, dan telur. Cookies memiliki karakteristik manis dan kaya akan lemak yang dibuat dengan menggunakan cetakan (Wulandari, dkk, 2010). Menurut Ariani, dkk (2018) keberhasilan membuat cookies yang baik tidak hanya bergantung pada resep, tetapi juga pemahaman tentang fungsi masingmasing bahan, kualitas bahan, komposisi bahan, proses pengocokan, pembentukan, pengovenan hingga proses pengemasan untuk menghindari kegagalan. Dalam pra eksperimen yang telah dilakukan peneliti mencoba 3 formulasi bahan, formulasi pertama yang telah dicoba yaitu tanpa ada perubahan bahan, formulasi yang kedua yaitu pengurangan tepung bonggol sebanyak 50 gram dan ketiga yaitu penambahan margarin 55 gram serta penambahan gula halus sebanyak 25 gram dengan hasil yang berbeda sehingga formulasi yang peneliti pilih yaitu menggunakan formula ketiga untuk margarin penambahan sebanyak 55 gram dan gula halus sebanyak 25 gram.

Beberapa penelitian tentang bonggol pisang sudah pernah dilakukan. Adapun penelitian yang menggunakan bonggol pisang kepok sebagai penelitian yaitu: pemanfaatan bonggol pisang kepok menjadi kerupuk (Badan Litbang Pertanian, 2013). Dalam penelitian ini peneliti memilih membuat produk olahan berupa choco cookies tepung bonggol pisang kepok karna ingin menambah kreasi dan inovasi baru terhadap jenis cookies yang umumnya hanya terbuat dari tepung terigu saja dengan adanya inovasi choco cookies tepung bonggol pisang kepok ini diharapkan dapat dijadikan sebagai alternatif dalam olahan aneka cookies dan dapat dijadikan sebagai usaha rumahan karna dapat mengurangi penggunaan tepung terigu sehingga dapat mengurangi biaya dalam pembuatan cookies tersebut.

Kualitas yang dimaksud dalam penelitian ini meliputi rasa, aroma, dan tekstur pada choco cookies tepung bonggol pisang kepok tersebut. Rasa merupakan kesan yang diperoleh indra pengecap yaitu lidah yang merasakan seperti manis, pahit ataupun masam, aroma merupakan hasil respon terhadap suatu produk yang dapat dinilai dari indera penciuman dan tekstur merupakan nilai raba pada suatu permukaan baik itu kasar, halus, lembut dan keras dalam suatu produk.

\section{METODE}

Metode penelitian adalah teknik atau cara yang digunakan dalam kegiatan penelitian sehingga, pelaksanaan dan hasil penelitian dapat dipertanggung jawabkan secara ilmiah. Penelitian yang digunakan adalah penelitian eksperimen. Penelitian eksperimen adalah penelitian yang dipergunakan untuk meneliti suatu objek dengan melakukan suatu percobaan secara nyata di lapangan (Arikunto, 2006). Penelitian ini dilakukan melalui percobaan membuat choco cookies dari tepung bonggol pisang kepok, sehingga mendapatkan hasil choco cookies yang sesuai dengan kreteria.

Proses pembuatan choco cookies ini menggunakan resep dasar dari (www.resepkoki.id, 2016) sebagai berikut:

Tabel 1

Resep Dasar Choco Cookies Tepung Terigu

Bahan:

\begin{tabular}{ll}
\hline Keterangan & $\begin{array}{l}\text { Resep Dasar Choco } \\
\text { Cookies Tepung Terigu }\end{array}$ \\
\hline Tepung & 200 gram \\
\hline Margarin & 125 gram \\
\hline Choco Chip & 150 gram \\
\hline Gula Halus & 125 gram \\
\hline Cokelat & 25 gram \\
\hline
\end{tabular}




\begin{tabular}{ll}
\hline Bubuk \\
\hline Kuning \\
Telur 1 butir \\
\hline Vanilli 1 sdt \\
\hline Proses pembuatan: \\
\hline No & Keterangan \\
\hline 1. & $\begin{array}{l}\text { Campur margarin dan telur ke } \\
\text { dalam mangkuk besar. Aduk } \\
\text { hingga rata. }\end{array}$ \\
\hline 2. & $\begin{array}{l}\text { Tambahkan gula halus dan vanilla } \\
\text { ke dalam adonan. Aduk lagi hingga } \\
\text { merata. }\end{array}$ \\
\hline 3. & $\begin{array}{l}\text { Di mangkuk terpisah, ayak tepung } \\
\text { bonggol pisang kepok dan coklat } \\
\text { bubuk. Aduk rata. Tambahkan } \\
\text { choco chip dan aduk kembali. }\end{array}$ \\
\hline 4. & $\begin{array}{l}\text { Masukkan adonan mentega ke } \\
\text { adonan tepung kemudian aduk rata } \\
\text { hingga membentuk adonan kue. }\end{array}$ \\
\hline 5. & $\begin{array}{l}\text { Cetak adonan kue menggunakan } \\
\text { sendok garpu }\end{array}$ \\
\hline 6. & $\begin{array}{l}\text { Oven selama } 30 \text { menit dalam suhu } \\
\text { 170 derajat. angkat dan dinginkan. }\end{array}$ \\
\hline 7. & $\begin{array}{l}\text { Menghasilkan } \pm \text { 600 gram choco } \\
\text { cookies. }\end{array}$ \\
\hline
\end{tabular}

Penelitian ini menggunakan tepung bonggol pisang kepok sebagai bahan utama dalam pembuatan choco cookies dilakukan pra eksperimen untuk mendapatkan choco cookies yang berkualitas baik. Choco cookies tepung bonggol pisang kepok diberikan kepada panelis untuk diuji kualitasnya dari aspek rasa, aroma dan tekstur. Uji kualitas yang digunakan uji organoleptik. Setiap panelis diberikan lembar uji observasi untuk diisi oleh panelis. Setelah data tersebut diperoleh akan dijabarkan secara sistematis dengan mempergunakan analisis deskriptif. Pembuatan choco cookies ini dilakukan dengan tahapan dalam eksperimen (1) tahap persiapan bahan (2) persiapan alat (3) tahap pengolahan.

Subjek pada penelitian menggunakan panelis terlatih. Subjek untuk uji kualitas choco cookies substitusi tepung bonggol pisang kepok berjumlah 19 orang yang diambil dari personal laboratorium tetapi dapat juga karyawan atau pegawai lain
(Soekarto, 1985), panelis untuk uji kualitas menggunakan 19 orang panelis yang terdiri dari 10 orang Guru SMK N 2 Singaraja, 5 orang Guru SMK Triyatma Jaya Singaraja, dan 4 orang Dosen Tata Boga Program Studi Pendidikan Kesejahteraan Keluarga.

Variabel adalah objek penelitian atau apa yang menjadi titik perhatian suatu penelitian (Arikunto, 2006). Dalam penelitian ini yang menjadi subjek penelitian adalah tepung bonggol pisang kepok yang akan dijadikan choco cookies dan objek dari penelitian ini adalah formula choco cookies tepung bonggol pisang kepok dan kualitas choco cookies tepung bonggol pisang kepok dilihat dari aspek rasa, aroma dan tekstur. Kualitas merupakan tingkat baik buruknya sesuatu yang dapat dinilai dari kesesuaian terhadap persyaratan produk. Kualitas choco cookies tepung bonggol pisang kepok ini dinilai dari beberapa faktor diantaranya yaitu rasa, aroma, dan tekstur. Rasa adalah hasil dari suatu produk yang dinilai dengan indra perasa atau pengecap, rasa dari choco cookies tepung bonggol pisang kepok ini yaitu manis dan gurih. Aroma adalah hasil respon dari indera pencium terhadap suatu produk makanan ataupun non pangan, aroma dari choco cookies tepung bonggol pisang kepok ini beraroma khas tepung bonggol pisang kepok. Tekstur merupakan hasil dari suatu produk yang dapat dinilai dari peraba permukaannya baik itu kasar, keras, lembut dan halus. Tekstur dari choco cookies tepung bonggol pisang kepok ini adalah rapuh.

Metode yang digunakan dalam penelitian ini adalah metode laboratorium dan metode observasi. Metode laboratorium adalah metode yang dilakukan dalam tempat khusus dilengkapi dengan peralatan untuk melakukan percobaan, Ani Isnawati (2016). Metode laboratorium digunakan untuk proses pembuatan choco cookies tepung bonggol pisang kepok. Metode observasi merupakan teknik pengumpulan data dengan pengamatan langsung (Hassan, 2002). Observasi digunakan untuk mengumpulkan data tentang kualitas 
choco cookies tepung bonggol pisang kepok ditinjau dari aspek rasa, aroma, dan tekstur. Untuk uji kualitas dari choco cookies tepung bonggol pisang kepok ini digunakan uji organoleptik yang meliputi rasa, aroma, dan tekstur. Penilaian organoleptik digunakan untuk meneliti mutu komoditif makanan. Uji organoletik disebut sebagai penilaian yang dilakukan dengan indera manusia atau sensorik.

Uji organoleptik yang digunakan dalam penelitian ini adalah uji mutu hedonik. Dalam uji mutu hedonik ini panelis diminta tanggapan pribadinya tentang kesan baik buruknya hasil penelitian dan menemukan tingkat mutu suatu produk yang disebut mutu skala hedonik. Panelis yang terpilih dalam penelitian ini adalah panelis terlatih yang berjumlah 19 orang yang akan menguji kualitas dari choco cookies tepung bonggol pisang kepok, panelis terlatih yang berjumlah 19 orang ini terdiri dari 4 dosen PKK dan 15 orang guru SMK. Panelis menanggapi dengan cara memberikan tanda chek list $(\sqrt{ })$ sesuai dengan kriteria yang telah ditentukan pada lembar observasi panelis terhadap kualitas choco cookies tepung bonggol pisang kepok yang berdasarkan tes skala mutu hedonik, data penilaian dapat ditransformasikan dalam skala numerik dan selanjutnya dapat dianalisis statistik untuk interprestasinya.

skala mutu hedonik dalam penelitian ini menggunakan rentangan sebagai berikut:

Tabel 2

Skala Mutu Hedonik Uji kualitas cake kulit pisang kapok

\begin{tabular}{cc}
\hline Skala Hedonik & $\begin{array}{c}\text { Skala } \\
\text { Numerik }\end{array}$ \\
\hline Kurang & 1 \\
\hline Cukup & 2 \\
\hline Baik & 3 \\
\hline
\end{tabular}

Instrumen yang digunakan dalam penelitian ini berupa lembar uji kualitas untuk panelis terlatih yang berjumlah 19 orang yang nantinya akan diberikan pada setiap panelis untuk menilai kualitas dari aspek rasa, aroma dan tekstur. Untuk mendapatkan hasil dan responden maka dibuat tolok ukur sebagai berikut:

Tabel 3

Tolok Ukur Uji Kualitas Choco Cookies

Tepung Bonggol Pisang Kepok

\begin{tabular}{|c|c|c|c|}
\hline Nilai & Rasa & Aroma & Tekstur \\
\hline 3 & $\begin{array}{l}\text { Manis dan } \\
\text { gurih }\end{array}$ & $\begin{array}{l}\text { Beraroma } \\
\text { khas } \\
\text { tepung } \\
\text { bonggol } \\
\text { pisang } \\
\text { kepok }\end{array}$ & Rapuh \\
\hline 2 & $\begin{array}{l}\text { Kurang } \\
\text { manis dan } \\
\text { gurih }\end{array}$ & $\begin{array}{l}\text { Kurang } \\
\text { beraroma } \\
\text { tepung } \\
\text { bonggol } \\
\text { pisang } \\
\text { kepok }\end{array}$ & $\begin{array}{l}\text { Kurang } \\
\text { rapuh }\end{array}$ \\
\hline 1 & $\begin{array}{l}\text { Tidak } \\
\text { manis dan } \\
\text { gurih }\end{array}$ & $\begin{array}{l}\text { Tidak } \\
\text { beraroma } \\
\text { tepung } \\
\text { bonggol } \\
\text { pisang } \\
\text { kepok }\end{array}$ & $\begin{array}{l}\text { Tidak } \\
\text { rapuh }\end{array}$ \\
\hline
\end{tabular}

Tujuan yang ingin dicapai dari penelitian ini adalah untuk mengetahui formula choco cookies tepung bonggol pisang kepok dan kualitas choco cookies tepung bonggol pisang kepok dilihat dari aspek rasa, aroma, dan tekstur. Sesuai dengan tujuan penelitian, maka analisis relevan untuk tujuan penelitian tersebut adalah metode analis deskriptif kualitatif dan deskriptif kuantitatif. Analisis deskriptif kualitatif yaitu suatu metode atau cara pengolahan data yang dilakukan dengan cara menyusun secara sistematis dalam bentuk kata-kata atau kalimat. Analisis deskriptif kuantitatif yaitu suatu cara pengolahan data yang dilakukan dengan jalan menyusun angka secara sistematis dalam bentuk presentase mengenai suatu objek yang akan diteliti, sehingga diperoleh kesimpulan umum (Agung, 1999).

Setelah dilakukan analisis data dengan menggunakan metode deskriptif kualitatif 
dan deskriptif kuantitatif terhadap data yang di uji kualitas choco cookies yang berbahan tepung bonggol pisang kepok sebagai pengganti tepung terigu, maka akan didapatkan suatu kesimpulan pada kualitas choco cookies tepung bonggol pisang kepok yang dilihat dari aspek rasa, aroma, dan tekstur sesuai dengan kriteria yang digunakan yaitu baik, cukup, kurang.

Berikut adalah rumus yang digunakan dalam proses analisis data terhadap kualitas choco cookies tepung bonggol pisang kepok sebagai berikut :

$$
\operatorname{Mean}(M)=\frac{\sum X}{N}
$$

Keterangan :

$$
\begin{array}{ccc}
\mathrm{M} & =\text { Mean ( rata-rata) } \\
\sum \mathrm{x} & =\text { Jumlah masing-masing } \\
\mathrm{N} & \text { skor (aroma, tekstur dan Rasa) } \\
\text { = Jumlah (sampel). }
\end{array}
$$

Rumus pedoman konversi dengan skala 3 (Tiga) :

$$
\begin{aligned}
& M+1 S D \longrightarrow M+3 S D \\
& M-1 S D \longrightarrow M+1 S D \\
& M-3 S D \longrightarrow M-1 S D
\end{aligned}
$$

Keterangan Rumus :

$$
\begin{array}{ll}
\mathrm{M} & =\text { Mean } \\
\mathrm{SD} & =\text { Standar Deviasi }
\end{array}
$$

(Koyan, 2012).

Keterangan :

$\mathrm{M}=$ Mean atau rata-rata dengan rumus:

$M=\frac{1}{2} \times($ Skor Maksimun + Skor Minimum $)$

$\mathrm{SD}=$ Standar Deviasi dicari dengan rumus :

$\mathrm{SD}=\frac{1}{6} \times($ Skor Maksimum - Skor

Minimum)

Skor Maksimum = 3

Skor Minimum $\quad=1$

Berdasarkan rumus diatas, untuk mencari konversi data yang telah terkumpul sehingga memperoleh hasil adalah dengan cara sebagai berikut :
$M=\frac{1}{2} \times($ Skor Maksimun + Skor Minimum $)$

$M=\frac{1}{2} \times(3+1)$

$M=2$

$\mathrm{SD}=\frac{1}{6} \times$ ( Skor Maksimum - Skor Minimum)

$\mathrm{SD}=\frac{1}{6} \times(3-1)$

$\mathrm{SD}=0,33$

Acuan pengambilan keputusan yang digunakan untuk menentukan kualitas choco cookies tepung bonggol pisang kepok ini dari aspek rasa, aroma, dan tekstur berdasarkan rumus pedoman konversi PAN dengan skala 3 (Tiga) sebagai berikut:

Tabel 4

Acuan Penentu Kualitas Choco Cookies Tepung Bonggol Pisang Kepok

\begin{tabular}{ccc}
$\begin{array}{c}\text { Rumus } \\
\text { konversi skala } \\
3\end{array}$ & $\begin{array}{c}\text { Acuan } \\
\text { pengambilan } \\
\text { keputusan }\end{array}$ & Kategori \\
\hline $\begin{array}{c}M+1 \text { SD- } \\
M+3 S D\end{array}$ & $2,33 \rightarrow 3,00$ & Baik \\
\hline $\begin{array}{c}M-1 S D- \\
M+1 S D\end{array}$ & $1,67 \rightarrow 2,32$ & Cukup \\
\hline $\begin{array}{c}M-3 S D- \\
M-1 S D\end{array}$ & $1,00 \rightarrow 1,66$ & Kurang \\
\hline
\end{tabular}

HASIL DAN PEMBAHASAN

Hasil dari penelitian ini adalah formula choco cookies tepung bonggol pisang kepok kemudian diuji kualitas dari aspek rasa, aroma, dan tekstur. Penelis yang digunakan adalah panelis pencicip terlatih yang berjumlah 19 orang panelis yang terdiri dari 4 orang dosen 15 orang guru SMK telah menguji kualitas choco cookies tepung bonggol pisang kepok. Data yang diperoleh kemudian di analisis menggunakan teknik analisis deskriptif kualitatif dan kuantitatif, sehingga diperoleh kesimpulan pada uji kualitas choco cookies tepung bonggol pisang kepok. Kualitas choco cookies tepung bonggol pisang kepok dilihat dari aspek rasa, aroma, dan tekstur dengan 
menggunakan 3 tingkatan skala mutu hedonik dengan katagori baik, cukup, dan kurang.

1. Formula choco cookies tepung bonggol pisang kepok sebagai berikut:

Tabel 5

Resep Dasar Choco Cookies Tepung Bonggol Pisang Kepok

\begin{tabular}{ll}
\hline Keterangan & $\begin{array}{l}\text { Resep Dasar Choco } \\
\text { Cookies Tepung Bonggol } \\
\text { Pisang Kepok }\end{array}$ \\
\hline Tepung & 150 gram \\
\hline Margarin & $180 \mathrm{gram}$ \\
\hline Choco Chip & $150 \mathrm{gram}$ \\
\hline Gula Halus & $150 \mathrm{gram}$ \\
\hline $\begin{array}{l}\text { Cokelat } \\
\text { Bubuk }\end{array}$ & $25 \mathrm{gram}$ \\
\hline Kuning Telur & 1 butir \\
\hline Vanilli & $1 \mathrm{sdt}$ \\
\hline
\end{tabular}

Proses pembuatan

\begin{tabular}{lll}
\hline No & Keterangan \\
\hline 1. & Campur margarin dan telur ke \\
& dalam mangkuk besar. Aduk \\
hingga rata.
\end{tabular}

2. Tambahkan gula halus dan vanilla ke dalam adonan. Aduk lagi hingga merata.

3. Di mangkuk terpisah, ayak tepung bonggol pisang kepok dan coklat bubuk. Aduk rata. Tambahkan choco chip dan aduk kembali.

4. Masukkan adonan mentega ke adonan tepung kemudian aduk rata hingga membentuk adonan kue.

5. Timbang adonan seberat 10 gram dan pipihkan menggunakan garpu, letakkan dalam loyang yang sudah diolesi dengan margarin.

6. oven selama 25 menit dalam suhu 170 derajat. angkat dan dinginkan..

7. Menghasilkan 650 gram choco cookies tepung bonggol pisang kepok.

Proses pembuatan choco cookies tepung bonggol pisang kepok mengalami perubahan resep yaitu pengurangan bahan tepung bonggol pisang kepok sebanyak 50 gram. Menurut Saragih (2013) kandungan air dalam tepung bonggol pisang kepok sebanyak 0,99\% karena kurangnya cairan dalam tepung tersebut menyebabkan adonan tidak bisa dibentuk serta tekstur mudah hancur, Kemudian dilakukan penambahan bahan margarin sebanyak 55 gram dan gula halus sebanyak 25 gram. Menurut Faridah, dkk, (2008) lemak atau margarin memberikan fungsi pada tesktur sehingga cookies/biskuit menjadi lebih lembut, berfungsi sebagai pengikat bahan dan pemberi rasa gurih. Penambahan gula halus sebagai pemberi rasa manis sekaligus menutupi rasa sepat dan ketir dalam tepung bonggol pisang kepok, dan juga berfungsi untuk memperbaiki tesktur saat di oven dimana akan menjadi proses pengkaramelisasi gula. Hal ini sejalan dengan pendapat menurut Sumanti, dkk (2010) menyatakan tepung bonggol pisang sebagai bahan baku pengganti terigu dalam proses pembuatan cookies, mempunyai rasa sepat atau ketir dikarenakan bonggol pisang terdapat getah yang mengandung saponin dan zat tanin dimana mempengaruhi rasa pada tepung bonggol pisang yang dihasilkan untuk diolah menjadi cookies. Dari hasil proses pembuatan choco cookies tepung bonggol pisang kepok menghasilkan choco cookies dari segi rasa manis dan gurih, dari segi aroma khas tepung bonggol pisang, dan dari segi tekstur yaitu rapuh.

2. Hasil uji panelis terhadap kualitas choco cookies tepung bonggol pisang kepok dapat dilihat melalui perhitungan data berikut:

1) Kualitas cake pisang dari aspek rasa.

$$
\begin{aligned}
& \text { Mean }(M)=\frac{\sum X}{N} \\
& \text { Mean }(M)=\frac{56}{19} \\
& \text { Mean }(M)=2,94
\end{aligned}
$$

2) Kualitas cake pisang dari aspek aroma.

$$
\operatorname{Mean}(\mathrm{M})=\sum \mathrm{X}
$$




$$
\begin{aligned}
& \text { Mean }(M)=\frac{55}{19} \\
& \text { Mean }(M)=\underline{2,89}
\end{aligned}
$$

3) Kualitas cake pisang dari aspek rasa.

$$
\begin{gathered}
\text { Mean }(M)=\frac{\sum X}{N} \\
\text { Mean }(M)=\frac{53}{19} \\
\text { Mean }(M)=\underline{2,78}
\end{gathered}
$$

Berdasarkan hasil perhitungan dari uji kualitas choco cookies tepung bonggol pisang kepok menyatakan kualitas dilihat dari rasa memperoleh skor 2,94 berada pada kategori baik sesuai dengan tolok ukur yaitu manis dan gurih. Dari segi aroma memperoleh skor 2,89 berada pada kategori baik sesuai dengan tolok ukur yaitu beraroma khas tepung bonggol pisang kepok. Tekstur choco cookies tepung bonggol pisang kepok memperoleh skor 2,78 berada pada kategori baik sesuai tolak ukur yaitu rapuh.

Hasil uji kualitas choco cookies tepung bonggol pisang kepok dapat dilihat pada diagram batang sebagai berikut:

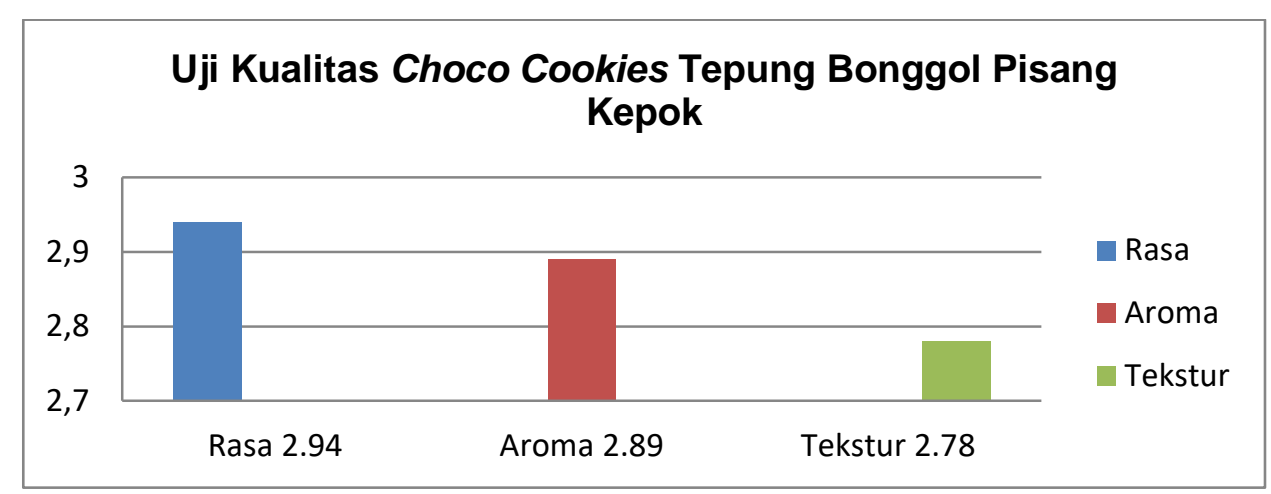

Diagram batang 01 . Hasil uji kualitas choco cookies tepung bonggol pisang kepok

Hasil uji kualitas choco cookies tepung bonggol pisang kepok yaitu dari segi rasa, aroma, dan tekstur yang diperoleh dari 19 panelis terlatih memperoleh skor rata-rata sebesar 2,94 termasuk dalam kategori baik.

a. Kualitas choco cookies tepung bonggol pisang kepok dari aspek rasa Rasa merupakan kesan yang diperoleh indra pengecap yaitu lidah yang merasakan seperti manis, pahit ataupun masam. Rasa dari suatu makanan merupakan salah satu komponen yang mempengaruhi makanan untuk daya tarik minat konsumen.

Ditinjau dari kualitas rasa choco cookies yang baik, choco cookies tepung bonggol pisang kepok berada pada kategori baik dengan skor 2,94 dan sesuai dengan tolok ukur yaitu manis dan gurih. b. Kualitas choco cookies tepung bonggol pisang kepok dari aspek aroma

Aroma merupakan hasil respon terhadap suatu produk yang dapat dinilai dengan bantuan indra penciuman yaitu hidung. Aroma dari suatu makanan merupakan salah satu komponen yang mempengaruhi daya tarik minat konsumen terhadap suatu produk tersebut. Ditinjau dari kualitas aroma choco cookies yang baik, choco cookies tepung bonggol pisang kepok berada pada kategori baik dengan skor 2,89 dan sesuai dengan tolok ukur yang ditentukan yaitu beraroma khas tepung bonggol pisang kepok.

c. Kualitas choco cookies tepung bonggol pisang kepok dari aspek tekstur

Tekstur merupakan nilai raba pada suatu permukaan baik itu kasar, halus, 
lembut dan keras pada suatu produk.Tekstur dari suatu produk merupakan salah satu komponen yang mempengaruhi tampilan produk. Ditinjau dari kualitas tekstur choco cookies yang baik, choco cookies tepung bonggol pisang kepok berada pada kategori sangat baik dengan skor 2,78 dan sesuai dengan tolok ukur yaitu rapuh.

Adapun masukan dari beberapa panelis yaitu menambahkan variasi bentuk cookies dan pada proses pengayakan tepung dilakukan 2 kali proses pengayakan agar mendapatkan tepung yang halus.

\section{SIMPULAN}

1. Formula choco cookies tepung bonggol pisang kepok setelah diuji coba maka diperoleh resep standar yang terdiri tepung bonggol pisang kepok 150 gram, margarin 180 gram, choco chip 150 gram, gula halus 150 gram, cokelat bubuk 25 gram, kuning telur 20 gram, dan vanilli 4 gram. Prosedur pembuatan a) campur margarin dan telur ke dalam mangkuk besar, aduk hingga rata, b) tambahkan gula halus dan vanilla ke dalam adonan aduk lagi hingga merata, c) di mangkuk terpisah, ayak tepung bonggol pisang kepok dan cokelat bubuk aduk rata kemudian tambahkan choco chip dan aduk kembali, d) masukkan adonan mentega ke adonan tepung kemudian aduk rata hingga membentuk adonan kue, e) timbang adonan seberat 10 gram dan pipihkan menggunakan garpu, letakkan dalam loyang yang sudah diolesi dengan margarin kemudian oven selama 25 menit dalam suhu 170 derajat.

2. Berdasarkan hasil uji kualitas choco cookies tepung bonggol pisang kepok yaitu rasa, aroma, tekstur yang diperoleh dari 19 panelis terlatih. Ditinjau dari kualitas rasa choco cookies tepung bonggol pisang kepok berada pada kategori baik dengan perolehan skor 2,94 dan sesuai dengan tolok ukur yang ditentukan yaitu manis dan gurih. Ditinjau dari kualitas aroma choco cookies tepung bonggol pisang kepok berada pada kategori baik dengan perolehan skor 2,89 dan sesuai dengan tolok ukur yang ditentukan yaitu beraroma khas tepung bonggol pisang kepok, ditinjau dari aspek tekstur choco cookies tepung bonggol pisang kepok berada pada kategori baik dengan skor 2,78 dan sesuai dengan tolok ukur yaitu rapuh.

\section{SARAN}

1. Kepada masyarakat bisa digunakan sebagai wirausaha ataupun produk kreatif untuk menggolah bonggol pisang kepok menjadi choco cookies karena secara ekonomis bonggol pisang kepok mudah didapatkan dan kurang dimanfaatkan menjadi hidangan yang tahan lama serta memiliki nilai jual yang tinggi seperti choco cookies.

2. Kepada peneliti lain yang ingin mengembangkan produk makanan menggunakan bahan utama yaitu tepung bonggol pisang kepok agar mampu memahami karakteristik tepung serta warna yang dihasilkan dari tepung bonggol pisang kepok berwarna coklat dalam hal ini untuk peneliti lanjut disarankan untuk membuat produk yang sesuai dengan warna tepung.

3. Untuk peneliti lanjut di sarankan untuk meneliti daya simpan choco cookies tepung bonggol pisang kepok.

\section{DAFTAR RUJUKAN}

Agung, Anak Agung Gede. 1999. Metodologi Penelitian Pendidikan. Singaraja : Sekolah Tinggi Keguruan Dan IImu Pendidikan.

Ani Isnawati, 2016. "Pusat Biomedis dan Teknologi Dasar Kesehatan". Http://www.litbang.depkes.co.id

Ariani, Risa Panti, Luh Masdarini, dan Gede Aditra Pradnyana. 2018. "Modified Cassava Flour Utilazion As A Wheat Flour Subsitution In Chochochip Cookies". Fakultas Teknik dan Kejuruan. 
Universitas Pendidikan Ganesha. $\mathrm{Htt}$ ps://easychair.org/publications/prepri $\mathrm{nt} / 9 \mathrm{~B} 3 \mathrm{~h}$

Arikunto, Suharsimi. 2006. Prosedur Penelitian Suatu Pendekatan Praktik, Ed Revisi VI. Jakarta : PT Rineka Cipta.

Badan Litbang Pertanian, 2013. "Kerupuk Bonggol Pisang: Dari Limbah Yang Kaya Gizi Ke Meja Makan Kita". Edisi 24-30 No.3504 Tahun 43. Http://www.google.co.id/url?q=http:// new.litbang.pertanian.go.id/downloa d/389/file/kerupuk-bonggol-pisang.p $\mathrm{df} \& \mathrm{sa}=\mathrm{U} \& \mathrm{ved}=2 \mathrm{ahUKEwj}$ Tr6ih3abiA hXML48KHf5YCv4QFjAAegQICBAB \&usg=AOvVaw3oyz5qP2ueT0pXwX AqQMA9

Dinas Statistik Kabupaten Buleleng. 2018."Buku Statistik Pertanian Dan Lingkungan Hidup Daerah". Https://b ulelengkab.go.id/assets/instansikab/ 126/layanan/buku-statistik-pertaniandan-lingkungan-hidup-daerah-201817.pdf

Faridah, Anni, Kasmita, Asmar Yulastri, dan Liswarti Yusuf. 2008. Patiseri Jilid 3. Jakarta : Direktorat Pembinaan Sekolah Menengah Kejuruan.

Hassan, 2002. "Metode Penelitian". Universitas Diponogoro. Https://eprints.undip.ac.id

Koyan, I Wayan. 2012. Statistik Pendidikan: Teknik Analisis Data Kuantitatif. Singaraja: Universitas Pendidikan Ganesha

Meliawati, Ni Luh, Cokorda Istri Raka Marsiti, dan Ni Made Suriani. 2016. "Reinventarisasi Makanan Tradisional Khas Kecamatan Busungbiu, Kabupaten Buleleng Sebagai Upaya Pelestarian Seni Kuliner Bali". Universitas Pendidikan Ganesha. Jurnal Bosaparis : Pendidikan Kesejahteraan Keluarga. $\begin{array}{llll}\text { Volume } & 4 & \text { No } & 1\end{array}$ Http://ejournal.undiksha.ac.id
Resepkoki. 2016. "Resep choco chip cookies (kukis)". Http://resepkoki.id/resep-choco-chipcookies-(kukis).

Saragih, Bernatal. 2013. "Analisis Mutu Tepung Bonggol Pisang Dari Berbagai Varietas Dan Umur Panen Yang Berbeda" Universitas Mulawarman. Jurnal TIBBS Teknologi Industri Boga dan Busana Volume 9 No $1 \mathrm{hlm}$ (22-29). Http://ejournal.um.ac.id

Sembiring, Sabarta. 2017. "Penggunaan Tepung Bonggol Pisang Kepok Hasil Fermentasi Dengan Saccharomyces Cerevisiae Dan Aspergillus Niger Sebagai Pakan Dan Implikasinya Terhadap Kecernaan Nutrien Dan Performan Ternak Babi Fase Grower" Universitas Brawijaya. Http://repository.ub.ac.id/953

Soekarto, S.T. 1985. Penilaian Organoleptik (untuk industri Pangan dan Hasil Pertanian). Jakart: PT BharataKarya Aksara

Sumanti, Debby Moody, Souvia Rahimah, Robi Andoyo, Asriyanti Septiani Gunawan. 2010. "Pengaruh Imbangan Tepung Bonggol Pisang Batu (Musa Brachycarph) dan Tepung Jagung Terhadap Beberapa Karakteristik Cookies". Jurnal Industri Teknologi Pertanian. Volume 4 ISSUE 1. Http://scholar.google.co.id/citations? user $=1$ Xf9B6sAAAAJ\&hl=en\#d=gs md_cita-d\&u=\%2Fcitaions\%3Fview op\%3Dview_citation\%26hl\%3Den\% 26user\%3D-1Xf9B6sAAAAJ\%26citati on_for_view\%3D1Xf9B6sAAAAJ\%3 AUeHWp8X0CEIC\%26tzom\%3D480

Wulandari, Mita dan Erma Handarsari. 2010. "Pengaruh Penambahan Bekatul Terhadap Kadar Protein Dan Sifat Organoleptik Biskuit". Universitas Muhammadiyah Semarang. Jurnal Pangan dan Gizi, Volume $01 \quad$ No. 02. Https://media.neliti.com/media/public ations/116310-ID-none.pdf 